\title{
The Material Value of Flags: Politics and Space in Northern Ireland
}

\section{Dominic Bryan}

In the first two decades of the twenty first century one of the most distinctive features of a tour around the streets of Belfast or Derry/Londonderry or the rural roads of Northern Ireland is the proliferation of flags hanging from lampposts, telegraph poles, or indeed almost any prominent point from which visibility can be profiled. Most common are Union flags, the Ulster banner (the old Government flag of Northern Ireland) and flags with varieties of "loyal" regalia, but neither does one have to look too hard in other areas to find the Irish Tricolour or flags of Irish Republicanism or global resistance. This feature of the landscape, the symbolic landscape, depends on the time of the year. In the first three months of the year the flags will be fewer in number, left from the previous year, very tatty and dirty, battered by the wind and rain of an Ulster winter. That is until we get to March and April, where in Nationalist working class areas at least, new sets of Tricolours are put up for St Patrick's Day and the commemoration of the Easter Rising. Many, but by no means all, are removed in May. By the end of May, Loyalists begin to put flags up the lampposts having removed any straggling material from the previous year. The displays increase until The Twelfth of July, the highpoint of "the marching season", by which time over 4,000 flags will be flying on the main roads alone. ${ }^{1}$ In September and October over half the Loyalist flags are removed although they might be added to in November by some commemorating the dead of two world wars. By Christmas the remaining flags are decayed, dirty, discoloured.

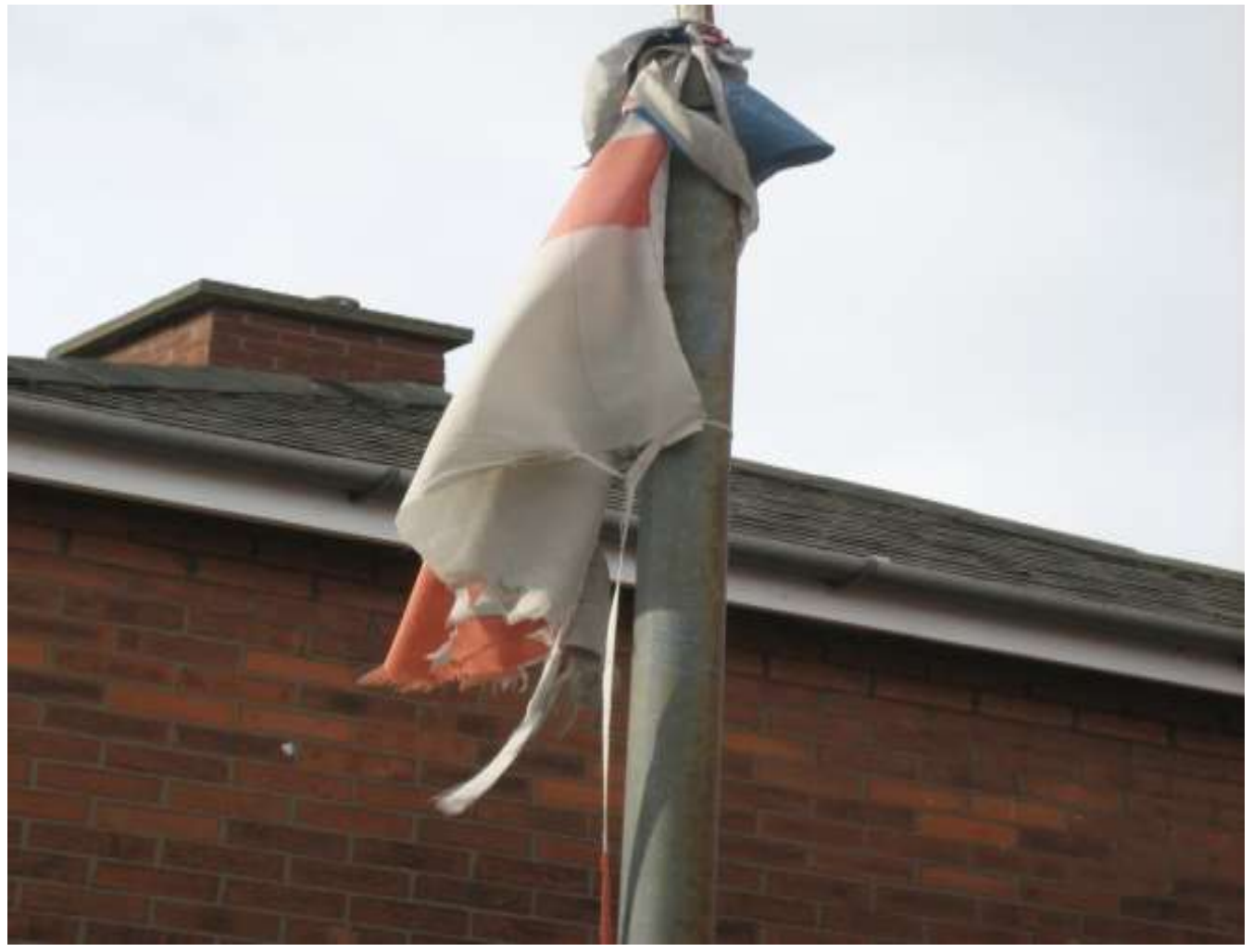

Figure 1: A tatty Ulster flag flies from a lamppost in East Belfast, 2007

\footnotetext{
${ }^{1}$ Dominic Bryan, Clifford Stevenson Gordon Gillespie and John Bell, Public Displays of Flags and Emblems in Northern Ireland: Survey 2006-2009 (Belfast: Institute of Irish Studies, 2010) <http://cain.ulst.ac.uk/images/symbols/bryan0510.pdf> accessed 09/10/17.
} 
In this paper I will discuss the history and meaning of these very distinctive displays. They are a version of commemorative practice, with a narrative of nationalism, which is reasonably popular throughout the world. But it is also very clearly a demarcation of territory in a society politically divided, with residential areas predominantly Catholic and Irish Nationalist and Protestant and British. And there is a sub-narrative of paramilitaries and social class as the flags normally go up in working class areas with paramilitary groups controlling the erection of flags. And they can do this, in part, because of the material and production of the flag. In part, there are so many because they are cheap. Historically a flag would have been a relatively expensive item used in special places and on special occasions and therefore looked after. They are looked after by being taken down and sometimes cleaned. In some countries, such as the USA, the ritual, rules and regulations demand that the flag is cared for. In Northern Ireland its value seems debased as knitted polyester version often printed on just one side leaves no reason for taking care, cleaning and reusing the item. Often produced in factories in Taiwan, the flag in Ulster has become a popular demarcation of ethno-political and paramilitary space. It has allowed creative new designs to add to the national flags creating a spatial narrative underpinned by a historical narrative with symbols that also attempt to legitimise illegal paramilitary organisations.

The 1998 All Party Agreement in Northern Ireland produced greater political stability after three decades of political violence. It also energised, what we might call, 'symbolic conflict' as Nationalists, newly empowered by the 'parity of esteem' promised in the document demanded space for the cultural symbols of Irish Nationalism and Republicanism in public spaces previously dominated by unionism and Britishness. Attempts by policy makers to mitigate this problem by planning for 'shared space' worked reasonably in the civic spaces of towns and cities but has little impact in residential areas. Whilst power was successfully shared by political parties the cheap flag has found a particular role in sustaining residential divisions across society.

\section{The Changing Symbolic Landscape}

Most of the flags that fly in the public spaces in Northern Ireland are very inexpensive. They are made of a cheap knitted polyester and are very light weight. They retail in local shops at between $f 5-£ 15$. They vary in size but most of them are five feet by three feet although since 2012, as an apparent response to the dispute over the number of days the Union flags flies above Belfast City Hall, there has been greater use of flags sometimes twice these dimensions. Hundreds are put up on lampposts, mainly in working class areas of the city and towns and rural villages. Since the cost of the flags has lowered, the possibility of putting two or three on a lamppost over some considerable distance can create impressive visual displays. They can be attached with cheap plastic ties that are fed through some simple metal eyes on the left-hand side of the flag. The resources that get put into this process do make a difference to the height of the displays. Those that can afford a "cherry picker" (also known as a Boom Lift or Basket Crane) can get their flags to the top of even the tallest lamppost. For the rest, the longest ladder dictates where on the lamppost the flag will fly. As such, many flags seem to be at half-mast. 


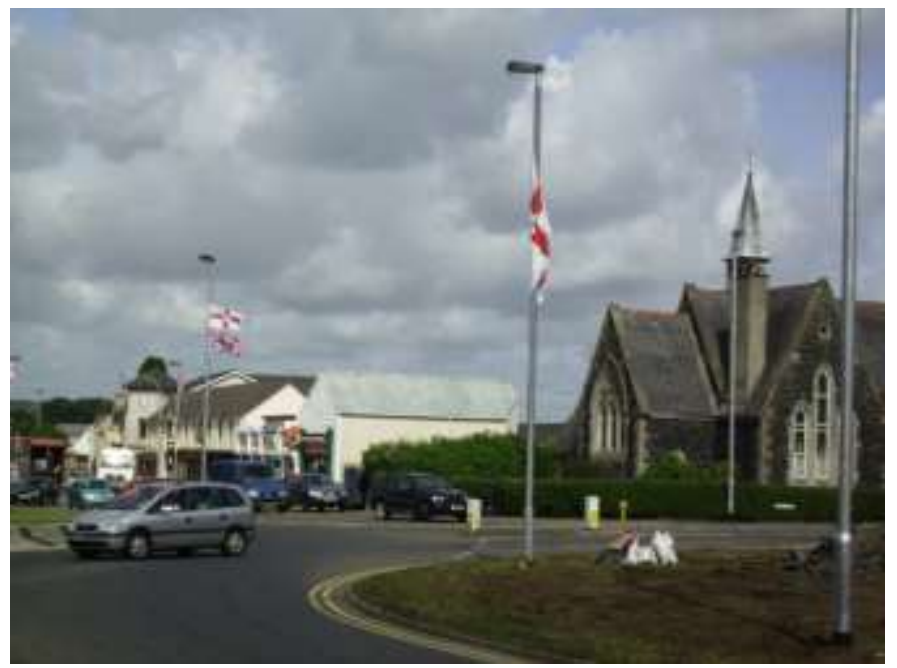

Figure 2: Flags in situ in County Down, July 2008

Technically this activity is illegal. Roads legislation necessitates that to use a lamppost for a particular display, such as a banner and hanging flower basket, requires 'authority'. ${ }^{2}$ This is only given to certain organisations such as the local Council. Any other displays are not legal. In addition, quite a number of these flags, which I will discuss in more detail presently, display symbols and words that link them to paramilitary organisations. This is particularly so of the two major Loyalist paramilitary groups, the Ulster Defence Association (UDA) and the Ulster Volunteer Force (UVF). These organisations are 'proscribed' under the Terrorism Act 2000 and, within the Act, showing support for these organisations is illegal.

In one sense, the widespread display of these cheap polyester flags is a development of a long-held commemorative "tradition" using large numbers of national flags. Yet they are also demarcations of paramilitary territory and acts of resistance by both Loyalists and Irish Republicans to the State and to each other. To further complicate the array of flags, they also demarcate different territories between the UVF, the UDA and the smaller Loyalist Volunteer Force. Indeed, as I will discuss below, it appears to have been the intra-conflict between these two Loyalist groups which actually helped create the present environment.

\section{A History of Flags}

Before I explore the impact of the significantly low cost of the contemporary displays of flags it is worth thinking about the context which broadly gives both the Union flag and the Tricolour high symbolic value. This context includes the historical narratives, through commemorative practice, that provides apparent legitimacy to the point where the flags are almost sacred. Since the establishment of the state, or quasi-state, of Northern Ireland, rituals and symbols have played a prominent role in defining the public space. Put simply, the public space, or civic sphere, was dominated by Unionism. In turn that Unionism, symbolised through displays of Britishness, viewed displays of symbolism from Catholic, Nationalist or Republican traditions as potentially threatening. It was this context, of course, that meant that the civil rights marches in the 1960 s were viewed as such a threat to a pro-Union status quo. ${ }^{3}$

\footnotetext{
2 Section 87, Roads Order (NI) 1993.

${ }^{3}$ Paul Nolan, Dominic Bryan, Clare Dwyre, Katy Hayward, Katy Radford and Peter Shirlow, The Flag Dispute: Anatomy of a Protest (Belfast: the Institute for the Study of Conflict Transformation and Social Justice, 2014),
} 
The period between the founding of the state and the Second World War was marked by economic and political insecurity. The Civil Authorities (Special Powers) Act (Northern Ireland) 1922 gave the state sweeping powers with which to 'keep the peace'. Although violence declined after 1925 the legislation became an effective tool used by the dominant Ulster Unionist Party. Republican and left-wing events were ideologically linked as a threat to the state and banned or restricted. In 1926 the Twelfth of July was declared a public holiday. After de Valera and Fianna Fail took power in 1932 in Eire there was a significant increase in the practice of parading by loyal organisations, such as the Orange Order, Apprentice Boys and the Royal Black Preceptories, in Northern Ireland. Between 1932 and 1936 loyal organisations were heavily restricted and threatened in the Irish state which drew angry responses in the north. ${ }^{4}$ In terms of the symbols and rituals in public space, Eire was going greener and Northern Ireland more Orange.

The manifestations of these commemorative days and marches had developed through the nineteenth century. Around the Twelfth of July Union flags would be displayed from houses, bunting strung over streets and imposing Orange Arches constructed across streets. ${ }^{5}$ This was true of all but the towns with a large Catholic population. Significantly, displays of flags would have often taken place on houses and for the flag to stay unsoiled for a reasonable period of time it would need to be taken in and washed. It is not easy to find evidence as to how long they would have been flown but before 1932 when the 'Last Saturday of August' was added to the marching season calendar it is likely flags were flown over the 'Twelfth Fortnight'.

During the same period displays of Irish nationalism, such as those on St Patricks Day and Lady's Day (August 15 $5^{\text {th }}$ ), and Irish Republicanism, around Easter, would have been restricted. ${ }^{6}$ On occasion quite large groups would attempt commemorative practices. In 1931 wreaths and Tricolours were placed at the Brandywell in Derry over Easter but were removed by police the following day. ${ }^{7}$ In 19335000 people tried to make their way to the Milltown Cemetery on the Falls Road despite being banned under the Special Powers Act and in 1937 police baton-charged people at the same commemoration. ${ }^{8}$ But the general position of the State was set, the Union flag was the dominant symbol representing Northern Ireland whilst the Tricolour was a threat to public order.

Disputes over flags and commemorative events remained routine after the war. In 1948 Home Affairs Minister Edmond Warnock banned a parade in Derry arguing that his government would not permit a Republican flag to be carried in Derry. ${ }^{9}$ The coronation of Queen Elizabeth II in 1953 produced a series of disputes over the flying of flags. ${ }^{10}$ In that year the Northern Ireland Government also introduced a new flag for Northern Ireland often

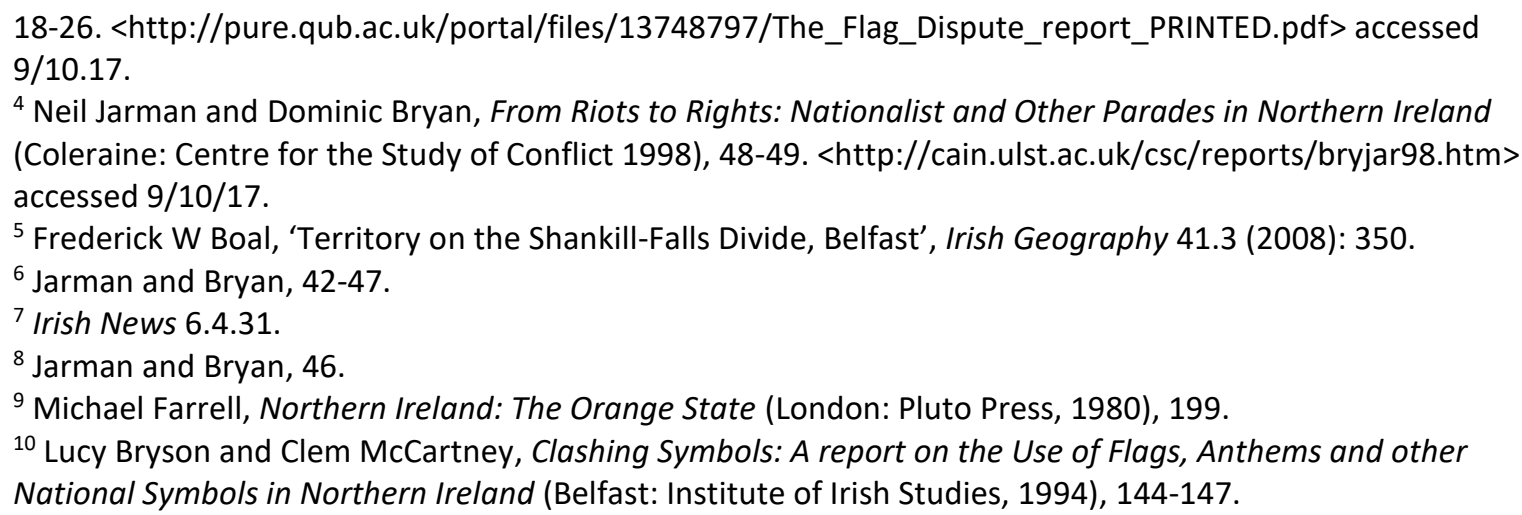


known as the Ulster Banner. ${ }^{11}$ One incident seems to have particularly influenced discussions on the displays of flags. After three houses in Derrymacash near Lurgan put up Union flags, Catholic neighbours put up 11 Tricolours. The police persuaded all to take down their flags so as to not escalate the situation. However, the removal of Union flags upset Unionists and they looked to get legislation changed. ${ }^{12}$ The 1954 Flags and Emblems Act was introduced to deal with the recurrent disputes over displays of the Tricolour. This Act gave the police specific powers to deal with any flag the display of which was likely to cause public disorder. However, the Union flag was excluded from the Act.

1. Any person who prevents or threatens to interfere by force with the display of a Union flag (usually known as the Union Jack) by another person on or in any lands or premises lawfully occupied by that other person shall be guilty of an offence against this Act.

2. Where any police officer, having regard to the time or place at which and the circumstances in which any emblem is being displayed, apprehends that the display of such emblem may occasion a breach of the peace, he may require the person displaying or responsible for the display of such emblem to discontinue such display or cause it to be discontinued; and any person who refuses or fails to comply with such a requirement shall be guilty of an offence against this Act. ${ }^{13}$

As such, the legislation, enforced by a predominantly Protestant police force, the Royal Ulster Constabulary (RUC), was most frequently used to prevent displays of the Irish Tricolour. Infamously, in September 1964 the Rev. Ian Paisley threatened to walk up the Falls Road and remove the Tricolour from the front window of the offices of the Republican Party. The attempt by the police to deal with the flag, not lan Paisley, led to serious riots. Such partisan management of symbols was seen again a few years later when members of the civil rights movement in Northern Ireland were refused the right to march into a range of towns in Northern Ireland whilst opposition protestors stood in the centre of those towns holding Union flags.

There are many examples of symbolic contestation during the post 1968 period. When placed next to the ongoing violence issues they take a lower public profile. Morris notes that in the 1970s, particularly around events such as the Ulster workers strike in 1974, there was an increase in the use of the Northern Ireland flag or Ulster Banner. In 1985 as Unionist anger grew over the Anglo-Irish Agreement, Unionist MP Harold McCusker was quoted as saying he might never fly the Union flag again. ${ }^{14}$ In the early 1980 s, connected to the politics of the Hunger Strikes, Republican murals started appearing in Nationalist areas. ${ }^{15}$

This flag's legislation remained in place right up until 1987 when new public order legislation removed the direct reference to flags. By that time the context in Northern Ireland had changed dramatically. The civil rights movement and clashes with the police between 1967-1972 were fundamentally about control of public space and it infamously ended in Derry with the events of Bloody Sunday. But the overall impact of this period is important for

\footnotetext{
${ }^{11}$ Ewan Morris, Our Own Devices: National Symbols and Political Conflict in Twentieth-Century Ireland (Dublin: Irish Academic Press 2005), 201.

12 Henry Paterson, 'Party versus Order: Ulster Unionism and the Flags and Emblems Act', Contemporary British History 13.4 (1999): 105-129.

131954 Flags and Emblems Act.

${ }^{14}$ Morris 2005, 204.

${ }^{15}$ Bill Rolston, Politics and Painting: Murals and Conflict in Northern Ireland (London: Associated Universities Press, 1991).
} 
understanding the way flags are flown in twenty first century Northern Ireland. First, violence and intimidation led to working class residential areas becoming more distinctively Protestant and Catholic. ${ }^{16}$ It created a greater sense of "territory" which became demarcated by walls, barriers and check points but also the painting of kerb stones, of murals and the use of flags. Second, the control of paramilitary groups in many of these working-class areas, the UVF and UDA in Protestant estates and the Irish Republican Army (IRA), Irish National Liberation Army (INLA) and a number of "dissident" Republican groups in Catholic estates, redefined the space and had an impact on the policing of the area by the RUC. Bluntly, these organisations carried out forms of "policing" themselves and the RUC struggled to maintain any legitimacy. It is perhaps less surprising in Nationalist areas, but this was also true of working class Loyalist areas. Third, in order to create a sense of legitimacy paramilitary groups began to play a more active role in commemorative practice with paramilitary displays from the IRA and other Republican groups in Nationalist areas and development of Loyalist paramilitary expression through the Unionist parading calendar. Loyalist paramilitaries utilised marching bands as a place to recruit and organise and through the 1970s and 1980s a range of paramilitary regalia, on drums and carried as flags began to appear in Orange parades. ${ }^{17}$ These bands, some but not all of which had paramilitary links, started to develop their own parades both commemorative and competitive thus increasing the scope and range of what is now known as "the marching season". And as a consequence, bands and paramilitary groups added their own symbolic repertoire to Orange, Black and Apprentice Boys parades and to the displays of flags that accompanied the summer months.

The political agreement in 1998 saw an end to high levels of violence, with over 3500 people killed since 1969 and many thousands injured, but the political environment was to lead to a heightening of what we might call symbolic conflict. First, in the public spaces and the political arena Nationalists and Republican displays had new legitimacy. The Agreement called for 'parity of esteem' and Section 75 of the 1998 Northern Ireland Act imposed statutory duties upon public authorities including, obviously, local Councils to promote equality of opportunity between persons of different religious belief, political opinion, racial group, age, material status or sexual orientation and promote good relations. So, for example, demonstrations by Republicans in the centre of Belfast and Derry/Londonderry became more commonplace with protestors climbing on Queen Victoria, in front of Belfast City Hall, and placing a Tricolour in her hand. From 1998 a St Patrick's Day parade developed in Belfast and whilst attempting to be "cross-community" inevitably led to lots of teenagers draped in cheap, polyester, Tricolours. The Tricolour had entered central Belfast, if not officially. ${ }^{18}$ Ironically, there have been constant efforts ever since to get people to use shamrock flags rather than Tricolours in order to maintain the potential that the event can be supported by all communities. The Tricolour no longer appears in the parade, but cheap flags are often wrapped around the shoulders of teenagers.

\footnotetext{
${ }^{16}$ Dominic Bryan, 'Titanic Town: Living in a Landscape of Conflict', Belfast 400: People, Place and History, ed. S.J. Connolly (Liverpool: Liverpool University Press, 2012).

${ }_{17}$ Neil Jarman, Material Conflict: Parades and Visual Displays in Northern Ireland (Oxford: Berg, 1997); Dominic Bryan, Orange Parades: The Politics of Ritual Tradition and Control (London: Pluto Press, 2000).

18 Dominic Bryan, 'Negotiating Civic Space in Belfast or The Tricolour: Here Today, Gone Tomorrow'. (Working Paper No. 13 Conflict and Cities and the Contested State, 2009).

<http://www.conflictincities.org/workingpapers.html> accessed 10/10/17.
} 
The second significant shift was the policing of Orange parades. These events, including the Twelfth of July and the commemoration of the Battle of the Somme on the First of July, had been largely uncontested until the 1970s and 1980s. Now, where these parades went through or past largely Catholic estates, residents, supported by Sinn Féin felt empowered to protest against the events. The RUC, to be reorganised into the Police Service of Northern Ireland (PSNI) in 2000, were not as prepared to give access to a parade regardless of the circumstances. Unionist hegemony was dissipating. So in 1995 they blocked significant parades in Portadown, Belfast and in Derry. ${ }^{19}$ What this created within unionism and amongst Loyalists was that the parades and all the associated displays were in part an act of resistance. The Orange State, as Farrell once controversially described, no longer existed. ${ }^{20}$ The symbolic landscape became significantly more contested.

The third key change was the development of policies, both under Direct Rule ministers to 2007 and then under a coalition all party government, that highlighted the importance of 'Shared Space'. ${ }^{21}$ Varieties of this policy attempted to both create civic space that was available for all but also to potentially undermine the highly territorial structures that had developed after 1970. In 2005 the Shared Future policy produced by OFMDFM under direct rule aimed to:

...to establish, over time, a shared society defined by a culture of tolerance: a normal, civic society, in which all individuals are considered as equals, where differences are resolved through dialogue in the public sphere, and where all individuals are treated impartially. A society where there is equity, respect for diversity and recognition of our interdependence. $(1.2 .1)^{22}$

\section{Flags on Government Buildings and Flags on Lampposts}

The 1998 Agreement made particular reference to the problem with symbols.

All participants acknowledge the sensitivity of the use of symbols and emblems for public purposes, and the need in particular in creating the new institutions to ensure that such symbols and emblems are used in a manner which promotes mutual respect rather than division. Arrangements will be made to monitor this issue and consider what action might be required. ${ }^{23}$

However, it was soon after the Agreement that the flying of flags became the site of contestation. The arrangement for Government Departments under the Agreement left the Ulster Unionist Party (UUP) in control of three Government departments, the Democratic Unionist Party (DUP) in control of two, the Social and Democratic Labour Party (SDLP) in control of three, and Sinn Féin in control of two. Unionist ministers ordered the flag to be flown outside their departments whilst Sinn Féin ministers ordered no flag to be flown. SDLP

\footnotetext{
${ }^{19}$ Neil Jarman and Dominic Bryan, Parade and Protest: A Discussion of Parading Disputes in Northern Ireland (Coleraine: Centre for the Study of Conflict, 1996). <http://cain.ulst.ac.uk/csc/reports/parade.htm> accessed 10/10/17.

${ }^{20}$ Farrell.

${ }^{21}$ Milena Komerova and Dominic Bryan, 'Introduction: Beyond the Divided City: Policies and Practices of Shared Space', City 18.4-5 (August 2014): 427 - 431.

${ }^{22}$ Office of the First and Deputy First Minister, A Shared Future (Belfast: Office of the First and Deputy First Minister 2005) <https://www.niacro.co.uk/sites/default/files/publications/A\%20Shared\%20Future\%20OFMDFM-Mar\%202005.pdf> accessed 10/10/17.

${ }^{23}$ The Belfast Agreement (also known as The Good Friday Agreement) 1998.

$<$ https://www.gov.uk/government/publications/the-belfast-agreement> accessed 10/10/17.
} 
ministers ordered the Union flag not to be flown on the Twelfth of July. This produced heated controversy in the Assembly and eventually a committee was established to explore the issue.

There was such contention that the then Secretary of State, Peter Mandelson introduced The Flags (Northern Ireland) Order 2000. This 'notified' particular days on which the Union Flag should fly on government buildings and designated the nine government buildings in Northern Ireland to which this would apply. The notified days (there were originally eighteen) in the main represented birthdays of members of the British Royal family. However, significantly the list did not include the Twelfth of July but did include St Patrick's Day.

In local councils, whose buildings were not covered under the new legislation, debates over flag-flying policies took place. In Nationalist controlled councils the policy of flying no flag was introduced whilst Unionist dominated councils flew it 365 days a year on more than one building. A few councils used designated days. Perhaps the key moment arrived on 3 December 2012 when the votes of Sinn Féin, the SDLP and the Alliance Party combined to introduce a new policy of flying the Union flag on Belfast City Hall on designated days. This produced indignation and anger among Unionists and Loyalists. This led to significant disturbances outside the building and was followed by weeks of protests and road blocks. ${ }^{24}$ Four years later there is still a protest in front of City Hall every Saturday.

Yet in terms of impact on people's lives we must return to the displays of flags on the roads and streets of Northern Ireland. As mentioned earlier, the use of lampposts and other forms of "street furniture" had been common for decades. ${ }^{25}$ For example in the late 1990s in Sandy Row, a working-class Protestant area of south Belfast large numbers of "Independent Ulster" flags appeared, rather than Union flags, over a number of years reflecting some of the policy directions of the UDA. But around 2000 the availability of the cheap flags created dramatic increase in the way space could be demarcated. Within the context of the 1998 Agreement there was some sharp divisions between a number of Loyalists groups. Loyalist Tommy Kirkham described events in the summer of 2000:

What happened was that a lot of flags went up after the UFF issued a statement to the Newtownabbey Times (newspaper), that because of daily events and the need to promote Protestant culture in general, it was putting up 1,500 flags from Greymount to Ballymena. ${ }^{26}$

He estimated that this had cost around $£ 1500-£ 2000$, little more than $f 1$ a flag.

Flags have always been a place for creative design, but this process essentially democratised it. They might not have been as distinctive as the well documented diversified political images of the murals in the 1980s and 1990s but, within Loyalist areas cheaply produced flags, that could now be designed on computers and printed in the Far East became a type of canvass for the expression of identity. The impact in Loyalist areas is particularly noticeable as the flags not only define unionism and loyalism but they are developing within the fractured and competitive space internal to Loyalism. So whilst Union Flags might be used as they have been in past decades a range of flags now links them to paramilitary groups through various historical narratives. Union flags hang from lampposts alongside the UVF

\footnotetext{
${ }^{24}$ Nolan et al, 29-45.

25 Boal.

${ }^{26}<$ http://news.bbc.co.uk/1/hi/northern_ireland/799804.stm> accessed 10/10/17.
} 
flags, which are claimed to be historical, but are understood by people to be put there by the contemporary paramilitary group.

In August 2000 a feud between the UDA and UVF in the Shankill Road became violent and the following year the two paramilitary groups, and the Loyalist Volunteer Forces (a breakaway group from the UVF in County Armagh) were actively defining their control of Protestant working class areas. And the defining of these areas could not be undertaken with the "traditional" Union flag or Ulster Banner as they were symbols shared by all the groups. The ability of these groups to produce designs on cheap polyester flags that incorporate historically important symbols led to the development of a range of designs representing different paramilitary groups and a variety of types of Unionism and Orangeism.

So, for example, the contemporary UVF claimed historical connection to the UVF of 1913, organised to resist the third Home Rule Bill. The '1913 UVF' provided many men for the $36^{\text {th }}$ Ulster Division at the start of the First World War and the $36^{\text {th }}$ Ulster Division played a key and bloody role of the Battle of the Somme in 1916. Thus there is a claimed historical link between the contemporary paramilitary organisation and a key battle of the First World War. This has been represented in a range of flags when combinations of symbols and terms link the UVF, the Battle of the Somme and other battles, the Poppy, the red hand and the crown. This process became even more obvious during the 'decade of centenaries' and the $100^{\text {th }}$ anniversary of the Battle of the Somme.



Figure 3: UVF '1912' flag from 2005 
Interestingly, the rival Loyalist group, the UDA, and their associated group the Ulster Freedom Fighters (UFF), do not have quite the same narrative available to them, since they were formed in 1972 and 1973. Their production of flags has involved the developments of crests and the use of pale blue on the UDA flags and of the clenched red fist on black UFF flags. In the early part of the twenty first century the feud between the UVF and UDA was so vicious that there were parts of Belfast where territories were marked out to particular lampposts each year. However, in other areas and more so in recent years, you can find places where UVF and UDA flags share the same lamppost.

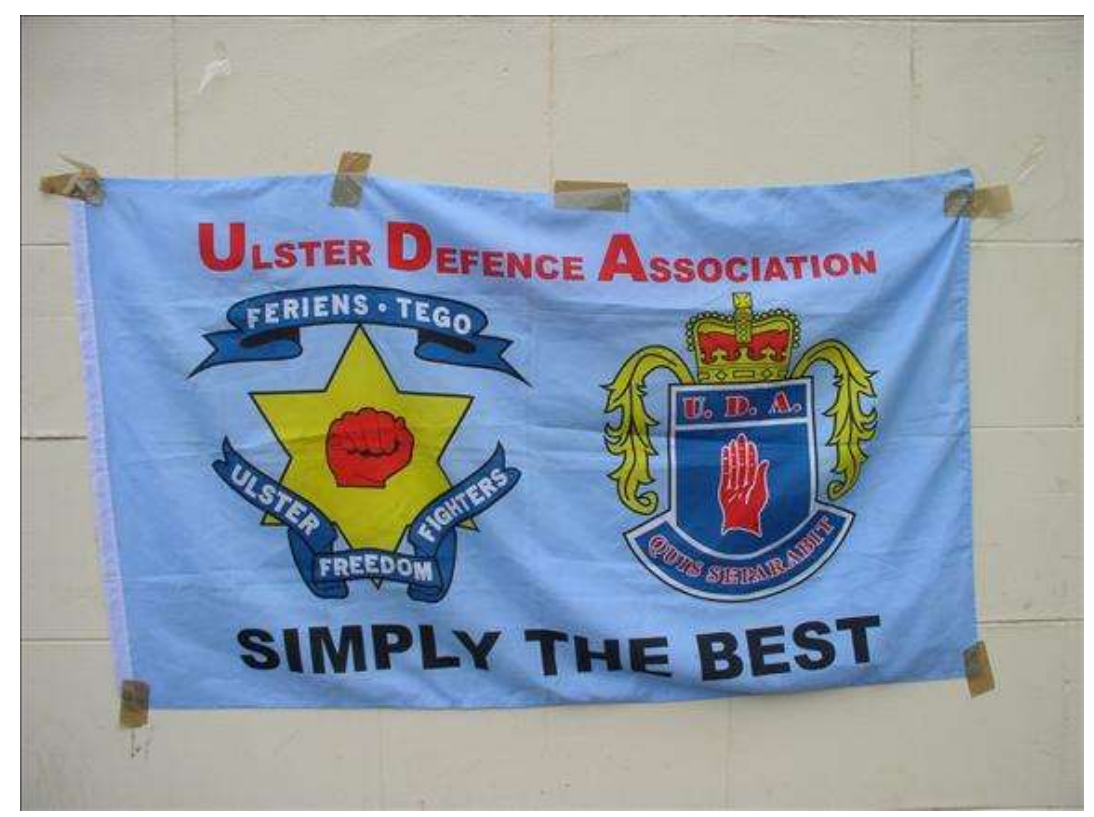

Figure 4: UDA/UFF 'Simply the Best' flag from 2005.

The proliferation of these flags across Northern Ireland is quite remarkable. Between 2006 and 2009 it was mapped by the Institute of Irish Studies at Queens University Belfast. They counted around 4000 flags put up annually on the main roads of Northern Ireland in July. ${ }^{27}$ If a count had taken place of residential areas this figure would increase dramatically. It is not unreasonable to estimate that $10,000+$ flags are put up annually. Of the flags counted around $50 \%$ were versions of the Union flag and a further $32 \%$ regional flags such as the flags of Northern Ireland (the Ulster Banner), Scotland and England. Around $4 \%$ of flags were paramilitary in orientation. ${ }^{28}$ Other categories counted included commemorative, sporting and the loyal orders, such as the Orange Order. Of the flags counted, $80 \%$ were flying from lampposts compared to $8 \%$ from private houses. ${ }^{29}$

The ease with which these flags can be designed and purchased means that Loyalists have been able to develop an impressive variety of designs. The Union flag appears through a variety of designs and is even displayed using different colours. For example, fans of East Belfast football team Glentoran will reproduce the Union flag using the team colours of green, black and red. Unlike the Tricolour, the distinctive design of the Union flag allows it to be reproduced in different colours and still be recognisable as the Union flag.

\footnotetext{
${ }^{27}$ Bryan et al 2010, 21.

${ }^{28}$ Bryan et al 2010, 22.

${ }^{29}$ Bryan et al 2010, 8.
} 


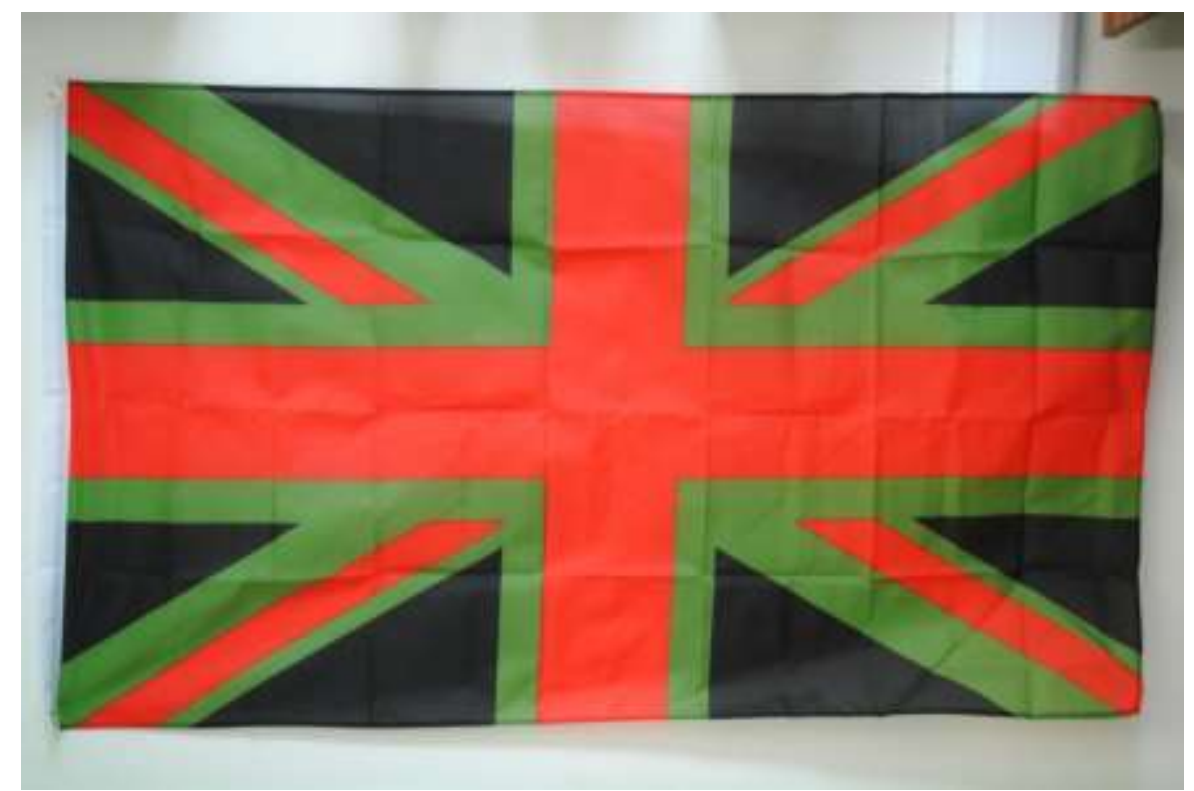

Figure 5: Union flag in the colours of Glentoran Football Club, 2005

Versions of the Union flag are produced with 'battle honours' from both World Wars, images of battles and more contemporary events as well as part of more complex designs and crests.

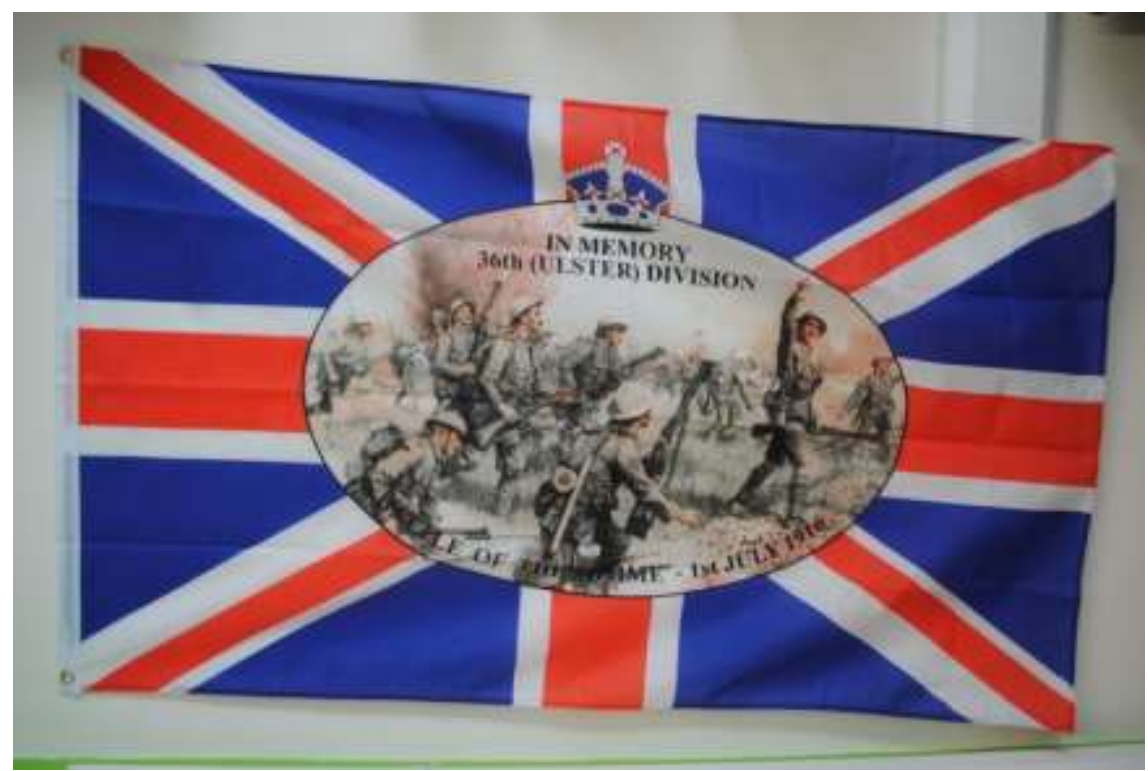

Figure 6: The Union Flag depicting the Battle of the Somme, 2005.

The Ulster Banner, formerly the official government flag of Northern Ireland, is still used in many circumstances including for the Northern Ireland team at the Commonwealth games. Designed from the Northern Ireland crest, it is a red 'cross of de Burgh', found on the Provincial flag of the 9th county Province of Ulster, on a white background with a red hand sitting in a six-pointed star (the six counties of Northern Ireland), with a crown on top. The version seen on the lampposts of Northern Ireland sometimes has a Union flag in the corner. There is also a version which combines it with the Israeli national flag by adding blue parallel lines at the top and bottom of the flag (Figure 7). The meaning of the six-pointed star is thus altered to suggest the Star of David. This flag seems to align the struggle of Loyalists against Republican 'terrorism' with that of the Israeli attempts to combat Palestinian violence. 
Palestinian flags can be found flying in Catholic working-class areas of Belfast, along with others from Basque and Catalan nationalist movements.

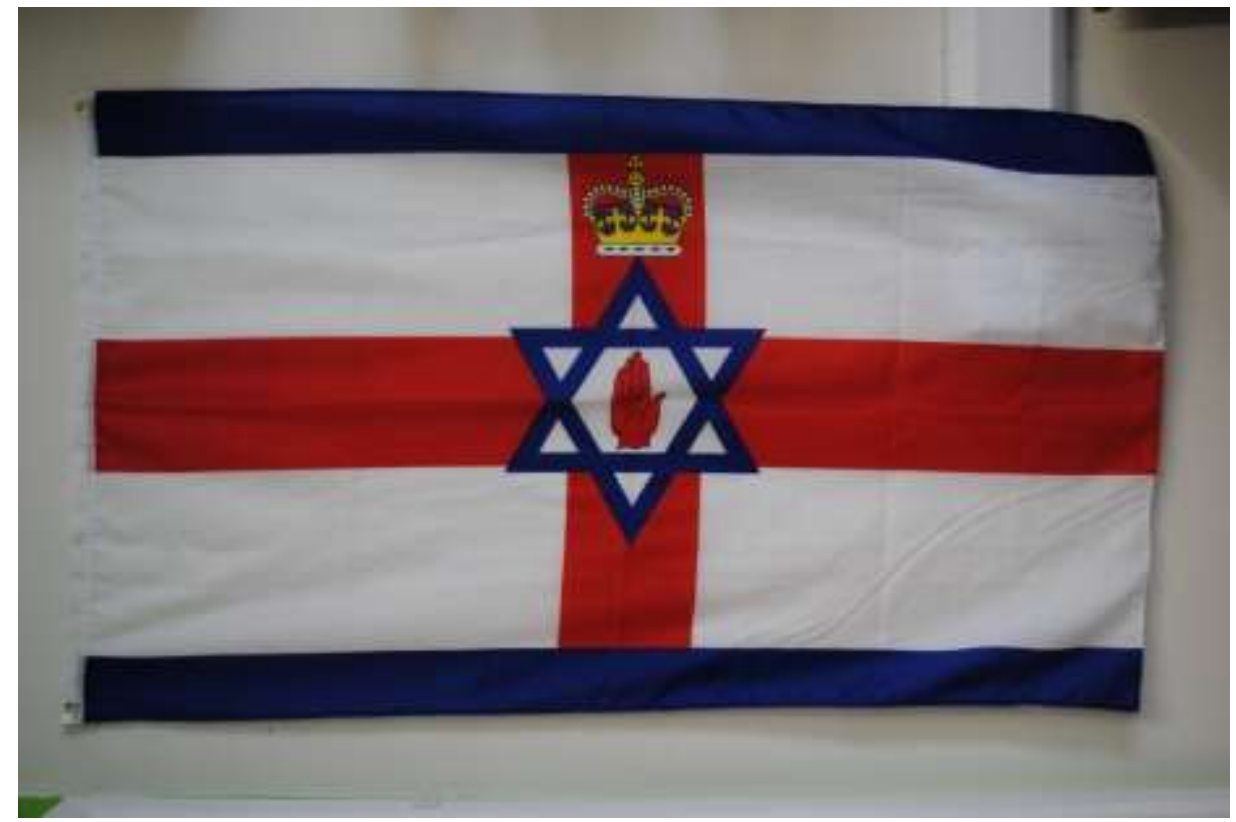

Figure 7: The Ulster banner and Israeli national flag combined.

Other designs on these cheaply produced flags represent football clubs, particularly Rangers Football Club in Protestant working class areas and Celtic Football Club in Catholic areas but also local football and Gaelic Association teams. Organisations including the Orange Order and Apprentice Boys of Derry are common as are depictions of British Army Regiments and crests including the Parachute Regiment inevitably lined with events of Bloody Sunday in 1972. Very often the flags produced on a particular year reflect forthcoming commemorations. There are a wide range of flags depicting the Battle of the Somme which particularly became numerous during the centenary anniversary in 2016.

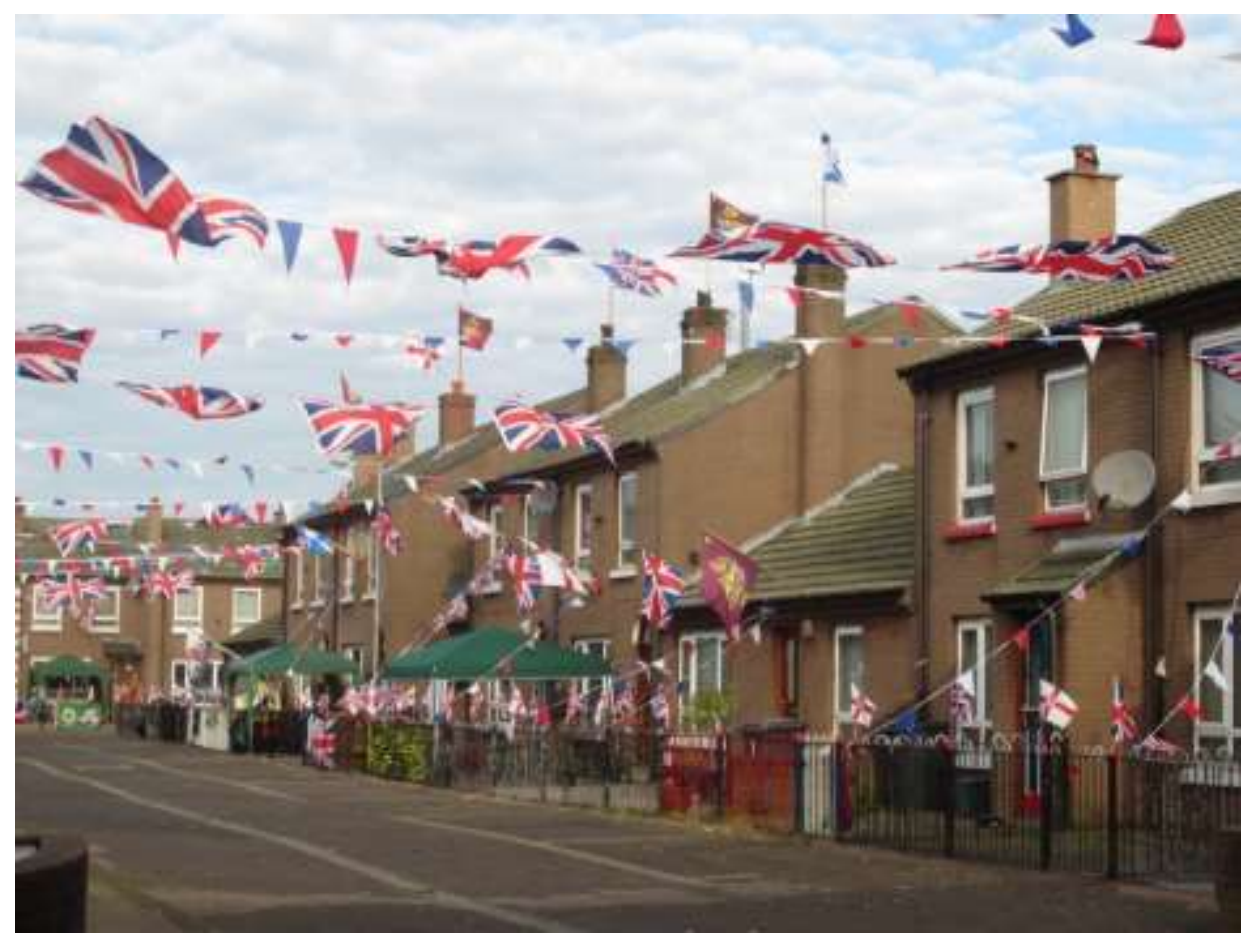

Figure 8: East Belfast 2017 
Since this survey was undertaken by the Institute of Irish Studies two processes have further increase the range and type of flags. A series of anniversaries, which in Ireland became known as 'the decade of centenaries' produced occasions important for Unionists. As such, the hundredth anniversary of the signing of the solemn league of covenant (2012), the setting up of the UVF (2013), the start of the First World War (2014) and the Battle of the Somme (2016) all produced newly designed flags. Because of the ease of design they included pictures of battles and important historical figures. The second event was the decision by Belfast City council on $3^{\text {rd }}$ December 2012 to only fly the Union flag on designated days rather than the previous 365 days a year. ${ }^{30}$ This produced an immediate response which included an increase in the use of Union flags and an increase in the size of some of the flags being flown.

The flags predominantly appear in Protestant working class areas. The range of designs and simply the numbers of flags is far less in neighbouring Catholic areas. In July, during the 2006-2009 survey periods, fewer than 300 would have been Republican or Nationalist flags. ${ }^{31}$ Even during the Easter period, when you would expect there to be the highest number of Nationalist flags, in 2009522 unionist flags were counted and 320 Nationalist and Republican on main roads. There is also not nearly the range of designs with Tricolours and "the starry plough" predominating. Flags with motifs of Celtic football club are not uncommon and flags of GAA counties and clubs appear of the particular team is doing well. That said, the $100^{\text {th }}$ anniversary of the Easter Rising in 2016 did see a wider range of flags produced that appeared in a wider range of places. In general, dissident Republican groups use the Tricolour and there is a smaller range of flags in Nationalist working class. It is noticeable that in areas where dissident Republican groups have a stronger presence that the Tricolour is left flying for longer.

It is important to note that whilst the sheer numbers of flags have an impact on the public space and on the sense of territory it only needs one or two flags flown at the entrance of an estate to demarcate the space. Perhaps most notably across the Belfast skyline an Irish Tricolour flies from the top of the twelve-floor New Lodge tower blocks all year round.

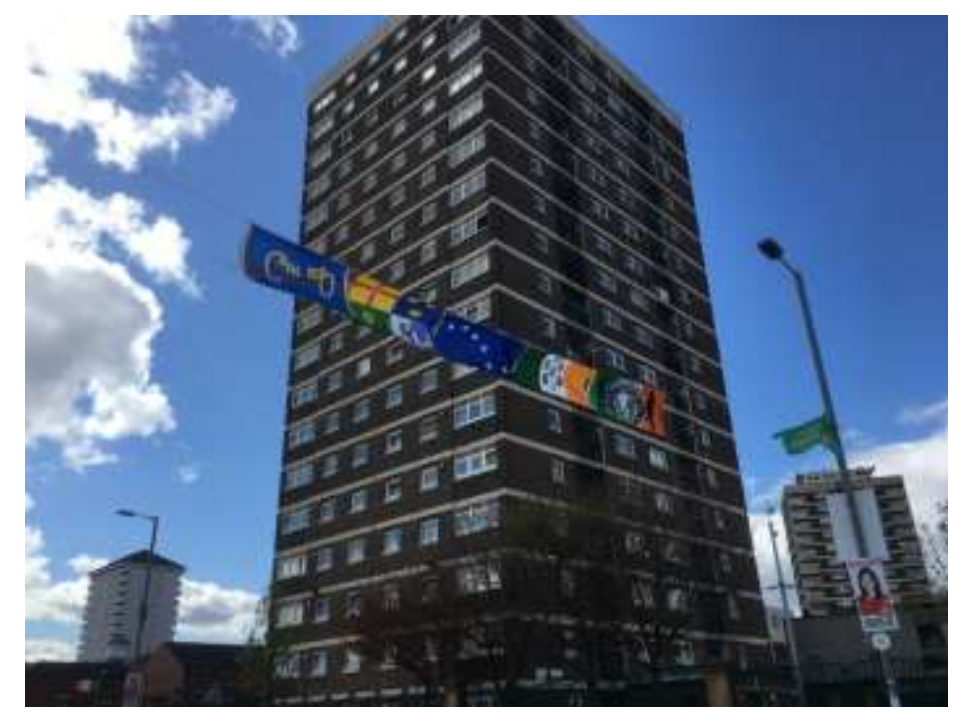

Figure 9: Republican Flags in North Belfast, Easter 2016. The flags are (from left to right) Cumann na mBan, the four Provinces of Ireland (Eagle of Connaught, Red Hand of Ulster, Crowns of Munster, Harp of Leinster), the Starry Plough, heroes of the Rising on a Tricolour and the contemporary gunman pictured with an East Lilly and the words 'Irish Republican Army Undefeated 19162016. The flag on the lamppost says, 'Irish Republic'.

\footnotetext{
${ }^{30}$ Nolan et al.

${ }^{31}$ Bryan et al 2010, 30.
} 


\section{Symbolic Value and Material Cost}

In the symbolic struggle for the production of common sense, or more precisely, for the monopoly over legitimate naming, agents put into action the symbolic capital that they have acquired in previous struggles and which maybe judicially guaranteed. ${ }^{32}$

Flags, but particularly national flags, are symbols used to represent social groups. People attach significant emotion to particular flags and they provide symbols of cohesion as explored the imagined communities of Anderson and the symbolically constructed communities of Cohen. ${ }^{33}$ Wide ranges of meanings are condensed to create an article that people identify with so that flags are of interest to those in marketing, to those protesting and to monarchs and presidents alike. Flags have 'cultural capital', or 'symbolic capital', in the social arena in what Bourdieu might call the labour of representation. ${ }^{34}$ Flags, particularly national flags, when being used in "official" circumstances are controlled through sets of rules about when, where and how they might fly. The national flag must usually fly above any other and must be lit at night. There is no better example of this than the American 'star spangled banner'. The wide range of videos that can be found on the internet reveal that the care of the national flag of the United States of America is no simple matter.

The national flag has the cultural capital of a sacred object. But what happens when you start to use it in alternative spaces, when "the people", or a section of people, take ownership of it. What happens if it is so cheap and easily available that it can used in very large numbers? What does this mean for the "value" of the flag? Does this change the symbolic capital?

Union flags, and other loyal symbols, have long been used in public displays in Northern Ireland. They would appear on arches, be flown from houses and strung as bunting across streets. But the flags were proportionally expensive and they were looked after. The ability not only to buy, but also to design, large numbers of "loyal" flags changed the relationship between people and the symbolic landscape. A high value symbol was available in thousands, on low quality material. Organised by paramilitary groups these flags have been put up and often left up. They are both sacred, so that the police and other agencies will not remove them, but also treated without respect. Nothing says Ulster lack a tatty flag. Those in official positions get upset at the use of the flag as a territorial marker but they have been powerless to "recover" the flag. Consequently, in Northern Ireland, the meaning of the Union flag, and to a lesser extent the Tricolour, has also become that of a territorial marker for paramilitaries.

A flag can simultaneously be the marker of official and legal sovereignty and can become the marker of local space. It can be emblematic of democracy but also the harbinger of fear. The display of a symbol can be defended as freedom of speech whilst also be criticised as intimidation. This is particularly evident in Northern Ireland where political divisions over the nature of the polity have often been expressed though violent conflict. Cheaply available flags shift the meaning of the object. They make its symbolic value available to be used, creatively, by a wider range of groups. In combination with the national flags, a range of other

\footnotetext{
32 Pierre Bourdieu, In Other Words: Essays Towards a Reflexive Sociology (California: Stanford University Press, 1990), 135.

${ }^{33}$ Benedict Anderson, Imagined Communities (London: Verso, 1983); Anthony Cohen, The Symbolic Construction of Community (London: Routledge, 1985).

${ }^{34}$ Pierre Bourdieu, Language and Symbolic Power (Cambridge: Cambridge University Press, 1991), 130.
} 
types of flags, allow for new narratives of power to be written on the symbolic landscape. Whatever the Union flag and the Tricolour mean in the rest of Great Britain and Ireland they have developed very particular meanings on the streets of Northern Ireland. 


\section{Works Cited}

Anderson, Benedict. Imagined Communities. London: Verso, 1983.

Boal, Frederick W. 'Territory on the Shankill-Falls Divide, Belfast'. Irish Geography 41.3 (2008).

Bourdieu, Pierre. In Other Words: Essays Towards a Reflexive Sociology. California: Stanford University Press, 1990.

Bourdieu, Pierre. Language and Symbolic Power. Cambridge: Cambridge University Press, 1991.

Bryan, Dominic. Orange Parades: The Politics of Ritual Tradition and Control. London: Pluto Press, 2000.

Bryan, Dominic. 'Negotiating Civic Space in Belfast or The Tricolour: Here Today, Gone Tomorrow'. Working Paper No. 13 Conflict and Cities and the Contested State, 2009. <http://www.conflictincities.org/workingpapers.html> accessed 10/10/17.

Bryan, Dominic. 'Titanic Town: Living in a Landscape of Conflict'. Belfast 400: People, Place and History. Ed. S.J. Connolly. Liverpool: Liverpool University Press, 2012.

Bryan, Dominic and Clifford Stevenson, Gordon Gillespie and John Bell. Public Displays of Flags and Emblems in Northern Ireland: Survey 2006-2009. Belfast: Institute of Irish Studies, 2010. <http://cain.ulst.ac.uk/images/symbols/bryan0510.pdf> accessed 09/10/17.

Bryson, Lucy and Clem McCartney. Clashing Symbols: A report on the Use of Flags, Anthems and other National Symbols in Northern Ireland. Belfast: Institute of Irish Studies, 1994.

Cohen, Anthony. The Symbolic Construction of Community. London: Routledge, 1985.

Farrell, Michael. Northern Ireland: The Orange State. London: Pluto Press, 1980.

Jarman, Neil. Material Conflict: Parades and Visual Displays in Northern Ireland. Oxford: Berg, 1997.

Jarman, Neil and Dominic Bryan. Parade and Protest: A Discussion of Parading Disputes in Northern Ireland. Coleraine: Centre for the Study of Conflict, 1996. <http://cain.ulst.ac.uk/csc/reports/parade.htm> accessed 10/10/17.

Jarman, Neil and Dominic Bryan. From Riots to Rights: Nationalist and Other Parades in Northern Ireland. Coleraine: Centre for the Study of Conflict, 1998. <http://cain.ulst.ac.uk/csc/reports/bryjar98.htm> accessed 9/10/17.

Komerova, Milena and Dominic Bryan. 'Introduction: Beyond the Divided City: Policies and Practices of Shared Space'. City 18.4-5 (2014): $427-431$.

Morris, Ewan. Our Own Devices: National Symbols and Political Conflict in Twentieth-Century Ireland. Dublin: Irish Academic Press, 2005.

Nolan, Paul and Dominic Bryan, Clare Dwyre, Katy Hayward, Katy Radford, Peter Shirlow.

The Flag Dispute: Anatomy of a Protest Belfast: the Institute for the Study of Conflict Transformation and Social Justice, 2014.

$<$ http://pure.qub.ac.uk/portal/files/13748797/The_Flag_Dispute_report_PRINTED. pdf> accessed 9/10.17.

Paterson, Henry. 'Party versus Order: Ulster Unionism and the Flags and Emblems Act'. Contemporary British History 13.4 (1999): 105-129.

Rolston, Bill. Politics and Painting: Murals and Conflict in Northern Ireland. London: Associated Universities Press, 1991. 